ISSN 0103-5150

Fisioter. Mov., Curitiba, v. 27, n. 3, p. 337-347, jul./set. 2014

Licenciado sob uma Licença Creative Commons DOI: http://dx.doi.org.10.1590/0103-5150.027.003.A004

\title{
Perception of the Family Health Program professionals about the need for insertion of physiotherapist in the team
}

\author{
Percepção dos profissionais do Programa Saúde da Família \\ sobre a necessidade de inserção do fisioterapeuta na equipe
}

Fátima Ferretti $^{[a]}$, Lisiele Lima ${ }^{[b]}$, Aline Zuffo ${ }^{[b]}$

[a] PhD, professor, Universidade Comunitária da Região de Chapecó, Programa de Pós-Graduação Stricto Sensu em Ciências da Saúde, Chapecó, SC - Brazil, e-mail: ferrettifisio@yahoo.com.br

[b] Graduate, Universidade Comunitária da Região de Chapecó, Chapecó, SC - Brazil, e-mail: lisiele@unochapeco.edu.br; alinezuffo@unochapeco.edu.br

\begin{abstract}
Introduction: Although the physiotherapist is provided by the Nucleus of support to family health (NSFH), is not expected in the Family Health Strategy team and, to this inclusion occur exist the need to reformulate the process of education in this area. Objective: To know the professionals' perception of the Family Health Strategy (FHS) about the need for insertion of the physiotherapist in the team. Materials and methods: A qualitative study in which data collection was carried out with interviews and field diary with subsequent content analysis. Results and discussions: The team affirms the need for insertion of the physiotherapist in the strategy, but their perception is that the therapist acts in the secondary and tertiary care. Final considerations: Therefore, it emphasizes the need for restructuring of educational projects to generate new knowledge that will bring the teaching-service, prioritizing a model of care focused on integral health care of the individual and the community, improving the education of physiotherapists for UHS.
\end{abstract}

Keywords: Family health. Physiotherapy. Insertion. 


\section{Resumo}

Introdução: Embora o fisioterapeuta esteja previsto no Núcleo de Apoio à Saúde da Família (NASF), ainda não está previsto na equipe da Estratégia Saúde da Família e, para que essa inclusão ocorra há necessidade de reformulação no processo de formação nessa área. Objetivo: Conhecer a percepção dos profissionais da Estratégia de Saúde da Família (ESF) sobre a necessidade de inserção do fisioterapeuta na equipe. Materiais e métodos: Estudo qualitativo em que a coleta de dados foi realizada com entrevistas e diário de campo com posterior análise de conteúdo. Resultados e discussões: A equipe afirma a necessidade de inserção do profissional fisioterapeuta na estratégia, no entanto a percepção destes é de que o fisioterapeuta atua nas atenções secundárias e terciárias. Considerações finais: Diante disso, ressalta-se a necessidade de reestruturação dos projetos pedagógicos para gerar novos conhecimentos que aproximem o ensino-serviço, priorizando um modelo de atenção focado na atenção integral à saúde do indivíduo e da coletividade, melhorando a formação do profissional fisioterapeuta para o SUS.

Palavras-chave: Saúde da Família. Fisioterapia. Inserção.

\section{Introduction}

The early 90s are highlighted as an important period in the consolidation process of the Unified Health System (UHS). In 1994 the Family Health Program (FHP) was created as a model of care that aimed at integrality and quality of health services (1).

However, many professionals working in the FHP were formed within a conception that favors the individual, curative and hospital-centered approach. This fact has been a challenge for these professionals, since they were organized in teams. In general, graduates of this education have difficulty transcending the medical office space, and then propose diagnoses and interventions at collective level, through an integral and humanized approach (2).

Historically marked by a model of curative and hospital care, being centered in medical consultation, the Brazilian health system lacked deep and radical changes, so that could meet the principles of the program. Reaffirming the principles of the UHS, the FHP has expanded rapidly and has assumed the status of "strategy" (3).

The basic health care, function of the Family Health Strategy (FHS), is characterized by a set of actions in health, individual and collective, which cover the promotion and protection of health, disease prevention, diagnosis, treatment, rehabilitation and maintenance of health, which must be developed through the exercise of managerial and health practices, democratic and participatory, in the form of teamwork, directed to populations of well-defined territories, for which assumes the responsibility for health, considering the existing dynamics in the territory in which these people live.

To make feasible the actions, each member of the strategy has specific attributions and also some collective, who are team responsibilities at work. However, in official documents, there are not specific attributions of the physiotherapist in the FHS, because this professional is not part yet of the basic composition of the team (4).

With the insertion of the physiotherapist, as well as other health professionals in public health programs, especially in the FHS, could improve the efficiency and solving the problems of this system, through a qualified team and able to promote health at all comprehensive levels. Isolated experiences in some Brazilian regions, demonstrate that the insertion of Physiotherapy in the Family Health Strategy further develops and enriches healthcare of the population (5). The presence of physiotherapy professional in the field of public health, would transcend the traditional context of their work, then changing the paradigm of care in office, outpatient hospital and clinic, then going to inspire a new model of care, favoring the promotion, prevention and recovery of health of the population (4).

A survey performed about the knowledge of 275 users in relation to physiotherapy and perception as to the needs of care, showed they still know physiotherapy, linked to aspects of rehabilitation or treatment and indicated that people who need Physiotherapy are disabled, injury patients or musculoskeletal pains, that 
physiotherapists work in hospital and not performs educational actions, although there are difficulties in accessing physiotherapy treatment. Of these, $98 \%$ considered it necessary to include the physiotherapist in basic health unit. It highlights that are currently low number of physiotherapists working in primary care and that there is a need for greater coordination of the physiotherapist with public health for the population to be benefited, and puts forth the need of reformulation of professional education of the physiotherapist for UHS (6).

Another study with physiotherapists and members of a team from the family health program of a municipality of Ceará, showed that users with professional insertion in the team, the access to services was facilitated and improved user satisfaction, but there are still several obstacles to overcome as insufficient number in these teams, the low participation of physiotherapists in primary care activities, structural and material difficulties, and especially the ignorance of the population, professionals and managers about the role developed by the physiotherapist in public health (4).

Loch-Neckel et al. (5) affirm not understanding why, at present, public policies do not include other professionals in various areas of health, such as occupational therapists, physiotherapists, psychologists, nutritionists, especially considering that the health is an inexhaustible field of knowledge and professional practice. The incorporation of new fields of knowledge, involving other professionals in this and other areas, such as engineering, social work, economics, sociology, architecture, pedagogy, would ensure integrality and sharing knowledge in daily practice, favoring the action planning focused in the complexity of the territories and families.

The insistence on the therapeutic act, as an intervention to reduce or solve a physical located problem, appears to be the centrality of the role of the physiotherapist, today. For this type of activity, these professionals find employment and professional recognition. It is worth mentioning that although physiotherapy is recent as a profession, is presented as one of the oldest fields of health, because the physical agents have been used for thousands of years in the treatment of diseases, and certain physiotherapy procedures built around this axis have shown undeniable effectiveness in the various areas in which they operate (7). Rather than enter the physiotherapist in the FHS, approaching it to the basic care, its integration to teams comprise the idea of creating intersection points, facilitating and encouraging the adoption of measures covering a view and a full health practice (8).

To know the perception of the FHS professionals regarding to the need of inserting the physiotherapist in the team, will allow us to think about new ways to enable favor the inclusion of this professional on the team, and give visibility to the problem. These searches can bring up a key issue which is the need to reformulate pedagogical projects of undergraduate courses in Physiotherapy, to include, for some, and to increase for others, the practices and disciplines in the area of public health, providing interaction among academics from various fields and FHS health teams, since graduation, in order to train more qualified professionals to serve the population according to the guidelines of the UHS, trying thereby, finally overcome the stigma that the physiotherapist acts just in rehabilitation (9).

Therefore, considering the context above, the present study aimed to investigate the perception of professional of four Family Health Strategy (FHS) of Chapecó about the need for insertion of physiotherapists in the team, as well as identify the knowledge of these professionals about physiotherapy and care demands to this area.

\section{Materials and methods}

This was a qualitative study conducted between March and April 2011, with professionals of four Family Health Strategies (FHS), of a municipality in western Santa Catarina. The population that participated in the study was intentionally selected to account for the research objectives and consisted of thirty-three FHS professionals, being three nurses, three doctors, three dentists, twenty four Community Health Agents (CHA). The only exclusion criterion was being minor.

The data collection instruments used were an interview with guiding questions regarding knowledge and perception of professionals of the Family Health Strategy (FHS) about the need for insertion of the physiotherapist in the team, the field diary and systematic observation of everyday FHS, as pre-established script. Initially we contacted with professional of the team in their workplace, where we present in a clear and objective manner, the purposes, objectives and method of data collection for this study. Trough agreement and 
cooperation in participating in the study, they signed an Informed Consent Form in accordance with guidelines and Regulatory Norms of Research Involving Human Beings of the Unochapecó Ethics Committee.

Following, we collected data, first with the routine observations of FHS, which were recorded in the field diary. After, we conducted interviews on a visit to their own work environment of team professionals, in previously scheduled time. The informations were obtained from a pre-prepared script, which assumes a guiding character for the realization, allowing the freedom and spontaneity of their opinions. The content analysis was performed according to Bardin (10). This study was approved by the Ethics Committee of the institution under No. 302/11 protocol.

\section{Results and discussions}

Regarding to the profile of study participants, we observed that thirty are females and three males, mean age of thirty-one years. The population that participated in the study consisted of thirty-three FHS professionals, being three nurses, three doctors, three dentists, twenty four Community Health Agents (CHA). In relation to schooling level, nineteen had $2^{\text {nd }}$ grade completed, all community agents, eight have postgraduate, three have completed $1^{\text {st }}$ grade and three $3^{\text {rd }}$ grade complete. Regarding the length of professional experience within the FHS, nineteen have two to four years, eleven between one and two years and three of four to eight years.

In the daily searched teams, they report that the demand for secondary and tertiary care is great and the team is composed of a small number of professionals, which affects the quality of work performed. Moreover, they are often responsible to perform incompatible practices to their area of education. This finding emerged a need to investigate the knowledge of these people about the actions of other professionals, who have not yet been entered in the FHS, such as physiotherapists, as well as, if there is need for such integration.

Knowledge of the FHS professionals about Physiotherapy/physiotherapist

In this aspect, the question of what was the knowledge of FHS professionals about the physiotherapist was addressed. After content analysis, we observed that emerged three thematic categories. The first highlighted the physiotherapist as one professional who acts only in rehabilitation, being the understanding of twenty-three professional of the team, in the second category, six professionals reported having no knowledge of the profession and only four respondents acknowledged that professional as someone who acts in health promotion.

$1^{\text {st }}$ category: Professional who acts

only in rehabilitation

We observed that the majority of respondents see the physiotherapist only in this aspect. This thought corroborates the idea of Rebellato and Botomé (11), noting that the very origin of physiotherapy directed settings for rehabilitation activities. The emergence of this professional was in consequence of the great wars, and then basically created to deal with physically injured persons. Until the 1980s, this performance was restricted to rehabilitation, following the historical logic that originated the regulation of this practice as a profession, just after World War 1940s. Was only in 1980, that education in Physiotherapy, through the redefinition of its object of study, pass to incorporate other sectors of intervention.

This aspect also explained by Ragasson et al. (12), noting that the vision about physiotherapy is reproduced in this context, because even after the change of work objectives and professional activities, the curricula of existing courses in Brazil still prioritized curative action, little valuing the current health care model. With the passage of time, this reality has imposed difficulties in inserting the physiotherapist in public health programs and also gave little attention to this professional in primary care, recognizing it as the secondary and tertiary actions, primarily in the rehabilitation fields.

Some of the interviewed professionals illustrate these concepts by answering what they know about the role of the physiotherapist. The social actor C. R. (43 years) reports that physiotherapy "works with rehabilitation of patients in several areas, both pre and post-operatively and in other areas related to this". C. S. (31 years) also said that this "works for improving and alleviate problems in the body, arms, legs, spine, when you have pain or a problem". Seeing this difficulty, the Physiotherapy courses have incorporated, sometimes 
more, sometimes less, prevention and promotion in their curriculum structures.

However, what we really need is that during the education, the students have practice with the FHS team. Rezende (13) points out that even today, after some changes in the structure of undergraduate courses, there is no impact on the professional profile, being still primarily targeted for rehabilitation clinics and hospital therapies centers. This practice leads to other professionals to see Physiotherapy only with intention to treat the disease already installed in the patient, which often prevents the incorporation of them in other sectors of health care.

Considering that the physiotherapist is not included in the FHS team, some professionals reported do not knowing the work of the physiotherapist in public health, because only those who needed some type of rehabilitation, already had some contact with this area. Reality highlighted in the category soon after.

$2^{\text {nd }}$ category: No knowledge about Physiotherapy

This aspect may disclose the little promotion of the profession, or even the lack of incentive for this practice. The role of Physiotherapy can be developed in all areas of health care. However, thanks to aspects of political, economic and organizational order, this profession is poorly divulged and developed in various media, since its most traditional form of action is linked to curative and rehabilitative areas, focusing on hospital practices, outpatient and clinics. This contrasts the new care models that involve the performance amid public health strategies. Given these characteristics, it is still too little known by network professionals (14).

Due to the lack of knowledge about Physiotherapy, some respondents report that they know nothing of the profession, such as social actor S. V. (27 years): "I do not know practically nothing". Similarly, we observed the reporting of T. B. (32 years): "I do not have much knowledge, so I prefer not to comment". This raises a concern regarding the multidisciplinary and interdisciplinary work between the active health, since they are unaware of the practices of other professionals.

These reports clearly demonstrate the lack of information and understanding of professionals about the physiotherapy. A challenge arises in that sense the area of knowledge and the institutions responsible for professional education, that they need to prepare these professionals to work and insert in teams, in an interdisciplinary way. The Ministry of Health (MH), together with the Ministry of Education (MEC), has created devices to redirect the process of education of health professionals as the National Program of Reorientation of Professional Education (Pro-Health) and the Education Program for Work (Epw-health), which prioritize the transformation of the educational process, knowledge generation and provision of services to the population, with integral approach of the health-illness process (4). Probably, depending on the educational institution present on its territory, have accessed these devices since 2005, we observed that some team professionals recognize the role of physiotherapist in primary care, more linked to health promotion practices, as described in the category below.

\section{$3^{\text {rd }}$ category: Professional who acts also in health promotion}

Despite the lack of understanding of the area, some professionals highlighted the Physiotherapy as active in health promotion and prevention. Mendes and Morais (15) points out that currently, the physiotherapist has expanded its area of performance in order to modify the previously adopted paradigm, who preached the access only rehabilitated of the profession. Let's see below interviewees reports about this issue. Z. K. (41 years), demonstrates to know more than their colleagues about the physiotherapist profession, when affirms that among its functions are "orientation in older age groups, teaching exercises, posture and walking". D. S. (32 years) complements, stating that "Physiotherapy is a healthcare profession that works with rehabilitation, health promotion and prevention". This new vision of the professionals is a positive sign with regard to changes in educational models, which has broadened the possibilities of inclusion of other specialties in the FHS and improve services to the population.

In Londrina (PR), is already possible to verify the inclusion of physiotherapist in the FHS. This was cited in the Trelha et al. work (16), highlighting the huge demand for the work of the physiotherapist who was in that region, especially with bedridden (sequelae of vascular stroke and elderly). Then arose the need to include these professionals in the FHS, in April 2002. The authors also mention, that the 
interventions follow in two levels: at first, provides care to bedridden patients and guidance to caregivers and, in other, care is provided to specific groups such as hypertension, diabetes, asthma and pregnant women, to prevent disease and promote health. This demonstrates the success of inclusion of physiotherapists in the team, covering all levels of activity, and not just rehabilitation. However, this inclusion mentioned above occurred for a need of rehabilitation.

Perception of the team about the need for insertion of physiotherapist in the FHS

When we questioned the team about their perception of the need for insertion of the physiotherapist, the thirty-three respondents said that the inclusion of the physiotherapist in FHS was required, based on the demands of health. But it is noteworthy that thirteen professionals had the perception that the insertion of the physiotherapist in the team, would only serve to improve user access to this service in a more welfare logic, highlighted in the first category below, nine respondents had the perception that this professional inserted in the team, would act primarily on rehabilitation, discussed in the second category, eight professionals reported that their integration would qualify the team's work, discussed in the third category, and only three professionals said the physiotherapist improve the prevention and promotion of health actions, which presents discussed in the last category of perception.

Perceptions clearly demonstrated a concept focused on centralizing welfare, in the unit, and focused on rehabilitation. This perception is so strong, because is this action that the team observed the professional performing on the profession routine. In this sense, physiotherapists need to leave their offices and take actions with a focus on community and family to change this reality. Below we present the categories presented in the previous paragraph, regarding perceptions of the professional team about the need for insertion of the physiotherapist in the team.

$1^{\text {st }}$ category: Physiotherapist in the team would improve the access of users in a welfare logic

About the subject Ribeiro (17), explains that this vision of the professionals interviewed is given by the fact that most physiotherapy appointments still restricted, mainly, to rehabilitation centers and other secondary care services, resulting in very high demand, which generates waiting lists, and people waiting for months for attendance.

Professionals working in the FHS realize it, because some of them talk about the great number of patients waiting for this attendance and the resulting queues. The social actor S. L. (32 years) pointed out that "there are many people who need it, and is waiting too long to be forwarded; if already had a 'physio' inserted in the team would be faster". The report of L. V. (32 years) also points to the lack of vacancies for this service: "It has a high rate of patients waiting to be called, the demand is very large, and the queue too".

At the same study Ribeiro (17), correlates another aggravating, which relates to the difficulty faced by most users to move to the service station. This difficulty becomes more complex both because of the physical limitations that many have, both from an economic standpoint, since this treatment requires repeated visits to the service, moving long distances, which represents, beyond the physical effort, transportation expenses. This reality is highlighted in the speech of S. V. (27 years): "Some patients are unable to leave home, and visits would help a lot". About this same aspect, C. S. (29 years) says that "the number of patients is very large, and it is very difficult to access the services. A physiotherapist already inserted in the FHS alleviates these indexes".

As a means of solving the problem, Castro et al. (18), mention that the role of the physiotherapist in the FHS should come with the aim of capturing the population repressed demand by difficulties, i.e., the proportion of people without access, where it passes to usufruct the service if the physiotherapist is brought closer to families. This subject is also rescued in the the work of Holdsworth and Webster (19), highlighting that the role of the physiotherapist in the FHS could reduce the demand of patients on the waiting list, accelerating the process of rehabilitation and health promotion. So, once the physiotherapist is inserted in the posts and in the community, it becomes easier to adhere to treatment, then decreasing the displacement and effort of patients to get to a particular place. It collaborates with the change in the care model, which avoids the increase of diseases at the same time that limited the damage and sequelae already installed. 
However, according to the perception of some professionals of the team, if Physiotherapy compose the team, would act only in tertiary care, which is justified because as noted in category one about knowledge, they know the professional as one who acts only in rehabilitation.

$2^{\text {nd }}$ category: Physiotherapists in the team would act primarily on rehabilitation

To explain this concept Ribeiro (17), highlights that the way as therapy has been entering the public health system is influenced by its appearance, because it had its genesis and evolution characterized by performance in rehabilitation. This distribution logic, for a long time, excluded the services of physiotherapy of basic network, which until today has caused great difficulty of access of the population to these services.

As a result of this history, the professionals have a limited perception in relation to the physiotherapist in the team, as can be illustrated by the report of the respondent J. C. (30 years), who claims to be necessary to include the physiotherapist on the team for him "to work with neurological problems, RSI, injuries, along with the team". In the same context, F. F. B. (35 years) presented his vision about the inclusion of the physiotherapist in FHS, considering the territory in which it operates: "In my area has many working in agricultural industries, and has much work accident, it would help a lot in the rehabilitation of these people".

There are other professionals that realize the need for insertion of the physiotherapist in the team, as a possibility to qualify and improve the work of the FHS, as highlighted in the third category of perception below.

$3^{\text {rd }}$ category: Physicotherapist would qualify the team's work

Loch-Neckel et al. (5), cites that professionals, regardless of the area they belong to, come from a scientistic training that makes them needy of the global understanding about the needs of the patient between the process of health-disease and are unaware of the practice of other professionals. The lack of incorporation of certain professions by the FHS impoverishes attendance, so the insertion of physiotherapists and other professionals in the programs, will improve efficiency and solving the problems of the population, through a qualified team. This vision is highlighted by some of the social actors, such as T. F. (37 years), who points out: "the other professionals do not know what the therapist knows. If would have one in a group will help a lot in our work". The interviewee A. B. (32 years) goes even further, saying that this insertion would be viable to contribute to the education of the group: "Till for us to have more knowledge is important". This clearly demonstrates the new vision of some health professionals about the other areas, and thus open up possibilities for improvement in knowledge and integration between these professionals.

This issue also corroborates with the perception of the respondent C. R. (41 years), as he reports: "Missing professionals able to work in this area, especially in the FHS which is broader. Several areas are still needy of this professional". Another way of thinking is highlighted by M. P. (32 years), who says: "This is a professional that complements the service and would not need to forward it".

The physiotherapy professional has the potential to work as a team and especially with human technology, having facility to participate in collective actions, as they have an education that includes a solid theoretical foundation in the field of public health and practices developed throughout the undergraduate (4).

Still regarding to the need for insertion of the physiotherapist into the team, some interviewees mentioned that this could act by improving prevention and health promotion, as they had an education oriented to these practices, as highlighted in the following category.

$4^{\text {th }}$ category: Physiotherapists would improve the prevention and health promotion

According to the Resolution of the Ministry of Education CNE/CES number 4, of February 19, 2002 with respect to the education of the Physiotherapist, according to their skills and competencies, the item dealing with the Health Care says that health professionals within their professional scope, must be able to develop actions of prevention, promotion, protection and rehabilitation, both individually and collectively. Each professional must ensure that their practice is conducted in an integrated and continuous form, with 
the other instances of the healthcare system, being able to think critically, to analyze problems of society and to seek solutions to them. Professionals must perform their services with the highest quality standards and the principles of ethics/bioethics, taking into account that the responsibility for health care does not end with the technical act, but with the resolution of the health problem, both individually and collectively (20).

Thus, it is clear that the actions in health promotion and prevention are included to the physiotherapist attributions, as highlighted Barros (21), the physiotherapist is currently refocusing its formation, with ethics, technical competence and social maturity to meeting the priority demands in health of our population. The weapons of this professional are their own hands, intelligence, emotion and nature, which complement and support in technical-scientific educational strategies, popular participation, prevention, treatment, development and rehabilitation of health through functional diagnostics, collective and social diagnostics, body approaches and others.

This is already perceptible in other levels of action in the health field, as cited by the social actor P. M. (27 years) that relates the importance of integrating physiotherapist in the team, so is possible "to assist in health promotion programs with lectures and guidelines in groups and homes. This would have greatly decrease the number of referrals out". Correlating with speaks of the social actor above Barbosa et al. (14) defend that during the operation, the physiotherapist aims to meet the demand in the community, reducing damage and injuries, with a full practice that direct from health education, reception, individual and group consultations, and conducting home visits.

\section{Role of the physiotherapist in the FHS team}

Although we observed that most of the issues addressed, the FHS professionals recognize the physiotherapist as one who acts more in rehabilitation, when asked about what should be the role of these professionals in the team, the reports were different. Of the team members, twenty-five said the physiotherapist should have a more focused work in the area of prevention and health promotion, eight highlighted that its performance should be even in individual rehabilitation. This shows that the team has the knowledge of what is expected of the performance of health professionals involved in a FHS, however, they suggest, by the perception previously presented, that the physiotherapist is not prepared to act in the FHS, therefore, continues to work primarily with disease and rehabilitation. Both categories are presented below.

\section{$1^{\text {st }}$ category: Working in health promotion and disease prevention}

Ragasson et al. (12), believe that physiotherapists can act in the FHS and primary care as a professional focused on education, prevention, collective and individual assistance, working in an interdisciplinary manner, participating in teams designed to planning, implementation, control and execution of projects and programs with basic health care actions, directly intervening in Public Health. This perception is recognized in the social actor speaks T. F. (39 years) that says the physiotherapist would act, "especially in group activities, with guidance, because if would meet each that need in the houses... should exist many physiotherapist for patient... (laughs)". This idea also stands out in the speech of another social actor (P. M., 27), when speaking about the work of the physiotherapist: "the main form, I think, is as a prevention form. The attendance in the houses would facilitate the bond between patient and therapist, as well as in groups, this is very important".

According to Rodrigues (22), the performance possibilities of the physiotherapist go to their suitability for public health policy advocated by the UHS, in which there is the valorization of prevention and health promotion, as well as the search of equity and better resolution of attendances provided, represents the main guiding elements of the proposed actions. In this sense, the reformulations of the pedagogical projects of the courses, inserting content in the area of public health, are fundamental.

However, even after the most highlight the need for professional work in health promotion and disease prevention, some professionals still cite the physiotherapist as who shall act only in rehabilitation, discussed below.

$2^{\text {nd }}$ category: Performance in individual rehabilitation

As already exposed throughout the article, this vision still prevails in the perception of the professional 
team. To explain this vision the author emphasize that was inserted in the public health services, taking services of secondary and tertiary (17) care. This distribution logic limits the Physiotherapy services to the basic network, which has caused great difficulty of access of the population to these interventions.

As the demands of working in primary care for Physiotherapy, regarding the opinion of the FHS professionals, some areas were cited with greater occurrence, and for 18 professional of the team, the demand is in the area of Occupational Health, 9 indicated the Orthopedics and Traumatology, 4 (12.1\%) professionals mentioned the area of Gerontology and 2 (6.1\%) the area of Health Promotion

We observed that most of these professionals have highlighted the area of Occupational Health as the main demand of action for Physiotherapy. This can be explained by the fact that the region covered by the health center comprises two large agricultural industries of the city, offering workspaces for the population. This means that eventually, these workers come to the unit already with the health compromised, due to work accidents and repetitive strain injuries.

Following this idea, the FHS professionals already agree with the insertion of a physiotherapist, with respect to this specific type of demand, however listing as priority the rehabilitation aspects and not prevention. This stands out in the speech of social actor D. S. (32 years) that relates physiotherapy with "Rehabilitation and prevention in the field of occupational health", corroborating yet with another idea, mentioned by N. K. (33 years), which says that physiotherapy act in "RSI, occupational health and bedridden". This is a worrying aspect, because these professionals cite physiotherapy performance in relation to the established injury, in a logical assistance, leaving aside the logic of FHS.

In another work demand, highlighted to Physiotherapy, is in the field of Orthopedics and Traumatology, being an area of high concentration of work for this professional, as previously mentioned. Let's see the report of the social actor A. B. (27 years) who points out that Physiotherapy would act in cases related to "orthopedic, bedridden and in cases of work accidents, the most found".

Although health promotion have been cited, still appears associated with the principle of secondary and tertiary care, as seen in the social actor speaks P. M. (28 years), which correlates this practice to "attendances in groups, with guidance, prevention and education in health, care at homes of the elderly and bedridden patients who can not leave home, the team as a way of belonging, and so on. (laughs)". However, for the Physiotherapy insertion within the Primary Care is necessary to break with this exclusive logic of individual care and overestimation of disease, in the strict sense that associates the profession to rehabilitation, as well as break the strong trend to develop isolated practices, distant interlocutions with other actors of the health and community. Only after the Physiotherapy reshape their professional practice, other health areas will better understand and recognize the various areas in which the profession can and should act .

\section{Final considerations}

We observed that professionals are favorable to the insertion of the physiotherapist in FHS team, however, emphasize that know this profession by the actions focused on rehabilitation. This factor suggests inserts difficulties of the physiotherapist in the team. This question leads us to the need to change that image and, an initial path occurs through reorganization of professional education models. Significant changes are needed in the education of therapists, from a complex process of transformation, that begins at graduation and continues throughout the development and education of these professionals, even after their inclusion in the work field.

In this sense, the Ministries of Health and Education have created devices to reorganize education in the area of health, in order to train professionals to meet the needs of the UHS, through the National Program of Reorientation of Professional Education (Pro-Health) and the Education Program for Work (Epw-health) in order to encourage restructuring of undergraduate teaching projects, generating new knowledge, approaching education-service and prioritizing a model of care focused on integral health care of the individual and the collective, however, there is a need of Physiotherapy, as a field, recognizing this need, because, otherwise, only the undergraduate Courses that have accessed these devices will fail to bring about the necessary change.

Also highlights the need for monitoring the effectiveness of the work generated by these programs, creating mechanisms to aggregate undergraduate courses in this movement of reorientation. We believe 
this would be a way to modify the situation of low insertion and underutilization of the physiotherapist in Public Health and consequently in the strategies which favor this action.

The most important limitation of the study lay in the fact that the territory in which the survey was conducted had not physiotherapist inserted in the team.

We emphasizes the importance of the debate and the articulation of new works and researches in this area to ensure the continuity of these dialogues, including users and physiotherapists, as well as FHS team. It is now up to Physiotherapy to propose strategies to overcome these issues and demonstrate its effectiveness about care in the field of Public Health. This path that has already been incorporated in some Brazilian regions, however, slowly and gradually.

\section{References}

1. Ciconi RCV, Venâncio SI, Escuder MML. Avaliação dos conhecimentos de equipes do Programa de Saúde da Família sobre o manejo do aleitamento materno em um município da região metropolitana de São Paulo. Rev Bras Saude Mater Infant. 2004;4(2):193-202.

2. Leite RFB, Veloso TMG. Trabalho em equipe: representações sociais de profissionais do PSF. Psicol Cienc Prof. 2008;28(2):374-89.

3. Brasil. Ministério da Saúde. Portaria n. 648, de 28 de março de 2006. Aprova a Política Nacional de Atenção Básica estabelecendo a revisão das diretrizes e normas para a organização da Atenção Básica para o Programa Saúde da Família (PSF) e Programa Agentes Comunitários de Saúde (PACS). Brasília, DF, 2006 (cited 2014 Jul 24). Available from: http://dtr2001.saude. gov.br/sas/PORTARIAS/Port2006/GM/GM-648.htm

4. Oliveira-Brasil AC, Brandão JAM, Silva MON, Godim Filho VC. O papel do fisioterapeuta no programa saúde da família do município de Sobral-Ceará. Rev Bras Promoç Saude. 2005;18(1):3-6.

5. Loch-Neckel G, Seemann G, Eidt HB, Rabuske MM, Crepaldi MA. Desafios para a ação interdisciplinar na Atenção Básica: implicações relativas à composição das Equipes de Saúde da Família. Cienc Saude Coletiva. 2009;14(Supl. 1):1463-72.
6. Carvalho STRF. Conhecimentos e percepções dos usuários da Estratégia de Saúde da Família sobre a Fisioterapia (dissertação). Ribeirão Preto: Universidade de São Paulo; 2009.

7. Nogueira JA. Fisioterapia no contexto da assistência domiciliar terapêutica: estudos de pacientes com AIDS (dissertação). Rio de Janeiro: Escola Nacional de Saúde Pública Sérgio Arouca; 2000.

8. Rezende M, Moreira MR, Amâncio Filho A, Tavares MFL. A equipe multiprofissional da 'Saúde da Família': uma reflexão sobre o papel do fisioterapeuta. Cienc Saude Coletiva. 2009;14(Supl. 1):1403-10.

9. Ferretti FT. Fisioterapia: considerações sobre uma ciência em construção. Ijuí: Unijuí; 2002.

10. Bardin L. El análisis de contenido. Madrid: Ahal; 2002.

11. Rebellato JR, Botomé SP. Fisioterapia no Brasil: fundamentos para uma ação preventiva e perspectivas profissionais. São Paulo: Manole; 1999.

12. Ragasson CAP, Almeida DCS, Comparin K, Mischiati MF, Gomes JT. Atribuições do fisioterapeuta no Programa de Saúde da Família: reflexões a partir da prática profissional. Revista Olho Mágico. 2006;13(2):1-8.

13. Rezende M. Avaliação da inserção do fisioterapeuta na Saúde da Família de Macaé/RJ: a contribuição deste profissional para a acessibilidade da população idosa às ações de saúde da equipe: um estudo de caso (dissertação). Rio de Janeiro: Escola Nacional de Saúde Pública Sérgio Arouca; 2007.

14. Barbosa EG, Ferreira DLS, Furbino SAR, Ribeiro EEN. Experiência da Fisioterapia no Núcleo de Apoio à Saúde da Família em Governador Valadares, MG. Fisioter Mov. 2010;23(2):323-30.

15. Mendes EC, Morais MIDM. O papel do fisioterapeuta em saúde pública no século XXI: uma abordagem em Parasitologia. In: Barros FBM, organizador. 0 fisioterapeuta na saúde da população: atuação transformadora. Rio de Janeiro: Fisiobrasil; 2002.

16. Trelha CS, Silca DW, Iida LM, Fortes MH, Mendes TS. 0 fisioterapeuta no Programa de Saúde da Família em Londrina (PR). Espaç Saude. 2007;8(2):20-5.

17. Ribeiro KSQ. A atuação da Fisioterapia na atenção primária à saúde. Fisioter Bras. 2002;3(5):311-8. 
18. Castro SS, Cipriano JG, Martinho A. Fisioterapia no Programa de Saúde da Família: uma revisão e discussões sobre a inclusão. Fisioter Mov. 2006;19(4):55-62.

19. Holdsworth LK, Webster VS. Direct access to physiotherapy in primary care: now? - and into the future? Physiotherapy. 2004;90(2):64-72.

20. Brasil. Ministério da Educação. Resolução CNE/CES n. 4, de 19 de fevereiro de 2002. Diretrizes Curriculares Nacionais do Curso de Graduação em Fisioterapia. Brasília, DF, 2002 (cited 2014 Jul 24). Available from: http://portal.mec.gov.br/cne/arquivos/pdf/ CES042002.pdf

21. Barros FBM. Apresentação: responsabilidade social. In: Barros FBM, organizador. O fisioterapeuta na saúde da população: atuação transformadora. Rio de Janeiro: Fisiobrasil, 2002. p. 7-9.
22. Rodrigues RM. A fisioterapia no contexto da política de saúde no Brasil: aproximações e desafios. Perspectivas Online. 2008;2(8):104-9.

Received: $10 / 18 / 2013$

Recebido: 18/10/2013

Aprovado: $14 / 05 / 2014$

Approved: 05/14/2014 